\title{
矩形断面柱のねじりフラッタについて* \\ ON THE TORSIONAL INSTABILITY OF PRISMATIC BARS WITH RECTANGULAR CROSS SECTIONS
}

\section{1. まえがき}

旧タコマ橋がねじりフラッタを生じて破壊したことは 周知のとおりである。風洞実験によれば，ねじりフラッ 夕はほとんどすべての構造物に共通して発生し, かつ, 多くの場合，ただちに大振幅に成長するものですこぶる 危険である。それにもかかわらず，ねじりフラッタにつ いては発生機構も含めて多くのことが現在なお不明であ る。この点, ギャロッピング（曲げフラッタ）と対蹠的 である。ギャロッピングについては，少なくとも高風速 に関する限りその発生機構は明らかであり, 準定常理論 を用いてかなりの精度でフラッタの発生を予知すること ができる1)。翼の失速フラッタ（ねじりフラッタ）に関 する研究は, ヘリコプタのロータ・ブレードに関連して 最近活発であるが2)，構造物のねじりフラッタに関する

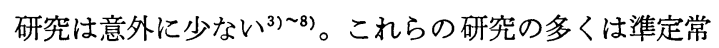
近似に基づいている。Steinman ${ }^{4}$ は本論文と同様に流 れの遅れの効果と準定常効果の両方を導入して問題を取 り扱っているが, 彼の論文にはいろいろな仮定が無差別 に取り入れられ, 従来批判が多い。Scanlan ら〕は, 翼 理論との類推により, 鈍い物体の迎角変化に対する Wagner 関数を求めているが, なお, 有効迎角の算定に 問題が残ると考えられる。

本論文の目的は, 二次元矩形断面柱を例にとり, 構造 物のねじりフラッタの発生機構を明らかにすることであ る。このため, 断面比の異なる 4 種類のばね支持式 1 自 由度ねじり振動用模型につき風洞実験を行ない，ねじり フラッタにおよぼすねじり軸位置†の影響を調べた。そ こでは，定常モーメント勾配の符号でねじりフラッタを

* 本研究の一部は構造物の耐風性に関する第 2 回シンポジ ウムにおいて発表

** 正会員 工博 九州大学教授 応用力学研究所 *** 正会員 工修 九州大学助手 応用力学研究所
中 村 泰 治** ・溝 田武 人*** By Yasuharu Nakamura and Taketo Mizota

予知しようとする，いわゆる $C_{M \alpha}$ による判別法が上記 矩形断面柱について検討される。ついで, 振動する鈍い 物体に作用する非定常空力ねじりモーメントが考察され る。最後に, 前縁にねじり軸がある場合のフラッタの発 生機構に関する推論と実験結果が示される。

\section{2. $C_{M \alpha}$ による安定判別}

ねじりフラッタに関しては, 従来より $C_{M \alpha}$ による安 定判別がある9。すなわち，ねじり軸まわりの定常モー メント勾配を $C_{M \alpha}$ (頭上げを正) とすると， $C_{M \alpha}>0$ ならば減衰, $C_{M \alpha}<0$ ならば発散といわれるものであ る。しかし, その根拠について明確な説明を与えた研究 は筆者らの知る限り見当 たらない。Farquharson は3), 図一1のように， 断面中央点 $P$ で角速度 $\dot{\theta}$ のねじり振動を行なう 物体を示し, 前縁におけ る流れの相対迎角 $\alpha$

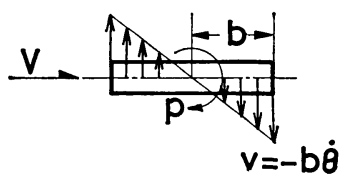

図-1 流れの中でねじり振動 する鈍い物体

$$
\alpha=-\frac{b \dot{\theta}}{V}
$$

および $P$ 点に関する定常モーメント勾配 $C_{M \alpha}$ を用い $\tau$, 角速度 $\dot{\theta}$ による空力ねじりモーメント $M(\dot{\theta})$ を,

$$
\begin{aligned}
M(\dot{\theta}) & =\frac{1}{2} \rho V^{2}(2 b)^{2} C_{M \alpha} \alpha \\
& =\frac{1}{2} \rho V^{2}(2 b)^{2} C_{M \alpha}\left(-\frac{b \dot{\theta}}{V}\right)
\end{aligned}
$$

で与えた。この場合， $C_{M \alpha}$ の正負に応じて，モーメン トが正あるいは負減衰となる。

Farquharson のこの説明は，前縁すなわち，はく離点

† 空力弾性学では二次元物体の並進と回転を曲げとねじれとい う用語で表現することが多い。ここでもある軸まわりの剛体 的回転運動をねじり軸まわりのねじり運動とよぶことにす る。同様に回転フラッタもねじりフラッタとよぶ。 
における有効迎角によりモーメントが決定されることを 意味し，いわば素朴な準定常流的説明であり，にわかに 承服し難いものであるが，一方， $C_{M \alpha}$ による判別その ものは実験的に妥当することが多いといらことも，これ まで漠然と認められているようである。本論文ではこの $C_{M \alpha}$ による安定判別の当否をまず検討することにした い。すなわち，ねじり軸位置をかえると，次節で示すよ らに $C_{M_{\alpha}}$ の值が変化するので，一方においてねじりフ ラッタの実験を行ない， $C_{M \alpha}$ の符号と衩じりフラッタ 発生の相互関係を調べる。実験結果を述べる前に, 簡単 な考察により得られる判別の適用限界を指摘しておきた い。それは次の二点である。

（1）高風速（無次元風速を指す）に限ること。すな わち，実用上は発振風速を推定することが重要である が，現段階ではそれはむずかしい。発振風速は多くの場 合，うずとの共振風速付近にあり ${ }^{10)}$ ，一般に，このよう な低風速では，うず含めて種々の二次的非定常効果が 大きく, 定常モーメント勾配による判別は必ずしも適用 できないと考えられるからである。事実，低風速で発振 し，高風速で減衰する例またはその逆もある11)。

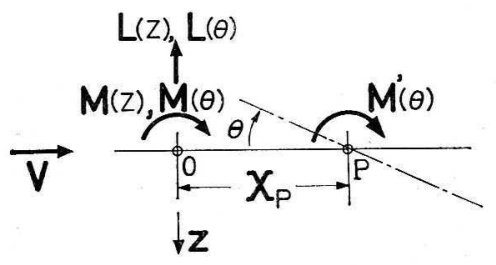

図一2 ねじり軸位置と非定常揚力 およびねじりモーメント
（2）ねじり 軸が物体近傍に ある場合に限る こと。図一2 に おいて, O点で 並進運動 $z$ と ねじり運動 $\theta$ を 行なら物体に作

用する非定常揚力およびねじりモーメントをそれぞれ $L(z), L(\theta)$ ならびに $M(z), M(\theta)$ とする。これらを 用いて, ねじり軸が $X=X_{p}$ だけ離れた $P$ 点で純ねじ り運動をする場合に $P$ 点に作用するねじりモーメント $M^{\prime}(\theta)$ を求める。線形性の仮定のもとに, 空気力をた とえば,

$$
L(z)=L_{z} z+L_{\dot{z}} \dot{z}
$$

とかき，以下， $L(\theta)$ なども同様に表わす。O点におけ る変位は $z=-X_{p} \theta, \theta=\theta$ で与えられるので, 運動の 安定性に関係する $M_{\dot{\theta}}^{\prime}$ は，

$$
M_{\dot{\theta}}^{\prime}=M_{\dot{\theta}}+\left(L_{\dot{\theta}}-M_{\dot{z}}\right) X_{p}-L_{\dot{z}} X_{p}{ }^{2}
$$

とかける。以下に $-M_{\theta}$ を空力ダンピングと称する。 特に，ねじり軸が物体の前後いずれでも遠く離れた場合 を考えると, 式 (4) で右辺第 3 項が卓越する。すなわ ち, 振動は並進運動に近くなり，その安定性はギャロッ ピングの判別 ( $L_{\dot{z}}$ あるいは無次元化して $C_{L \alpha}+C_{D}$ の 符号）で定まり， $C_{M \alpha}$ の符号と無関係となる。よって， $C_{M \alpha}$ によるねじりフラッタの安定判別は物体近傍に軸 がある場合に限り成りたつべきものである。

\section{3. ねじりフラッタにおよぼすねじり軸位置の 影響}

断面比 1:1，1:2，1:4 および 1:5の 4 種よりな るばね支持式の 1 自由度ねじり振動用矩形断面模型を, 風洞気流内で断面短辺を気流に垂直に置く（平均迎角 $\left.0^{\circ}\right)$ 。ねじり軸位置を断面対称軸に沿って $x_{p}=X_{p} / b=$ -2〜2.5（前縁および後縁はそれぞれ $x_{p}=-1$ および 1）までかえねじりモーメントの無次元空力ダンピン グ $k_{a}$ (aerodynamic damping) を自由振動法により測 定する。別に 6 分力風洞天秤で求めた定常モーメント勾 配 $C_{M \alpha}$ と振動実験で求めた $k_{a}$ とを比較し， $C_{M \alpha}$ に よるねじりフラッタ判別の検詩を行なら。 $k_{a}$ の值は, 単位幅当りの空力ねじりモーメントを $M(\theta)$ として次 式で算出する。

$$
\begin{aligned}
& M(\theta)=M_{\theta} \theta+M_{\dot{\theta}} \dot{\theta} \ldots \ldots \\
& k_{a}=-\frac{M_{\dot{\theta}}}{\rho f b^{4}}=\frac{2 I}{\rho b^{4}} \delta_{a} \\
& \delta_{a}=\delta-\delta_{0} \ldots \ldots \cdots \cdots \cdots \cdots
\end{aligned}
$$

ただし，

$$
\begin{aligned}
& \rho: \text { 空気密度 } \\
& b: \text { 半弦長 }(=1 / 2 d) \\
& f: \text { 振動数 }
\end{aligned}
$$

$I$ : 単位幅当りの模型の慣性モーメント

$\delta:$ 気流中の系の対数減衰率

$\delta_{0}:$ 静止空気中の系の対数減衰率

表一1 模 型 諸

\begin{tabular}{c|c|c|c|cc}
\hline 模型 & $1: 1$ & $1: 2$ & $1: 4$ & $1: 5$ \\
\hline$h$ & 0.15 & 0.075 & 0.0375 & 0.03 \\
$d$ & 0.15 & 0.15 & 0.15 & 0.15 \\
$d / h$ & 1 & 2 & 4 & 5 & h \\
$l$ & 0.6 & 0.6 & 0.6 & 0.6 & \\
$D$ & 1.0 & 0.5 & 0.25 & 0.25 \\
\hline
\end{tabular}

振動実験に使用した 風洞は高さ $\times$ 幅 $=3 \mathrm{~m} \times 0.7 \mathrm{~m}$ の 二次元風洞である。模型は合板製で，表一1 に示すよう に，弦長と幅が同一で断面比に応じて高さをかえてあ る。なお, 流れの 二次元性を確保す るために，模型の 両端に円形の端板 を取り付けた。端 板の直径と模型の 高さとの比はでき るだけ大きいほう が望ましいがそそ れだけ重量が増す

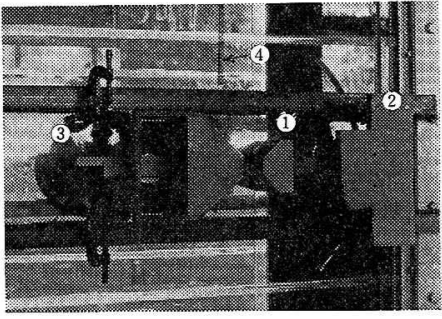

(1)十字板ばね (3)軸移動用スライド部 (2)電磁ダンパー (4)補助コイルばね

写真一1 風洞測定部と模型支持装置 


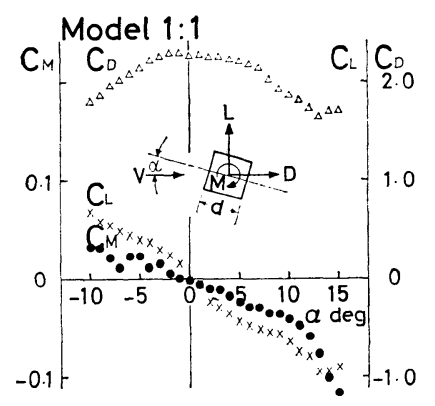

(a)

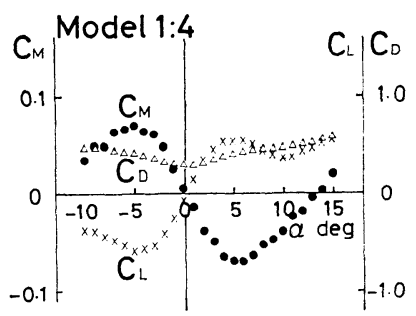

(c)
Model 1:2

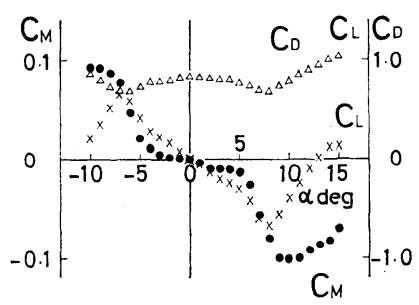

(b)

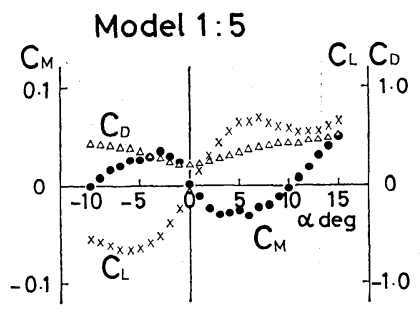

(d)

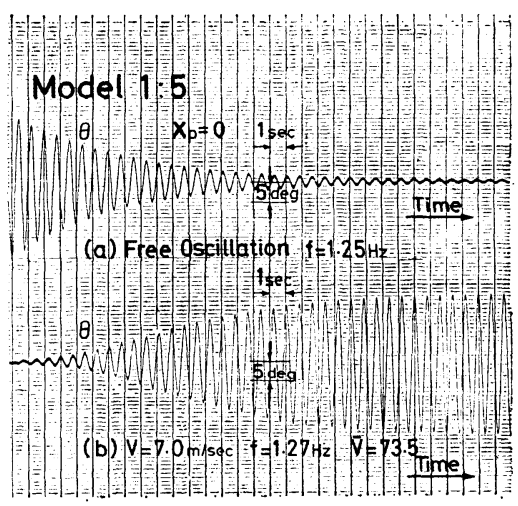

図一4オッシログラフの記録例

Model $1: 2$

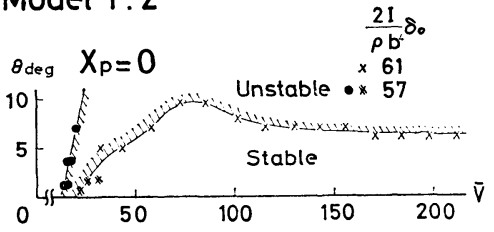

図一5 リミット・サイクルの振幅
ので振動模型としては工合が悪い。ここでは, 静的 3 分 力特性の測定において許し得た最低の值をとった（D/h $=6.7)$ 。模型は測定部中央で水平に置かれ，1 自由度ね じり振動が許されるように雨側壁外で十字ばねと補助コ イルばねで支持された（写真一1）。ばね系剛性の直線性 は $\pm 25^{\circ}$ の範囲で良好であった。ねじり角は十字板ばね にストレンゲージをはり検出された。模型の固有振動数 は約 $f_{0}=0.3 \sim 1.5 \mathrm{~Hz}$ ，風速は約 $V=1 \sim 10 \mathrm{~m} / \mathrm{s}$ (レイ ノルズ数 $\left.R=0.1 \sim 1 \times 10^{5}\right)$ であった。なお, 振動発散 の烈しい場合には，電磁ダンパーを使用して発散率を制 御した。その場合, 式 (7) に扔ける静止空気中の対数 減衰率 $\delta_{0}$ が電磁ダンパーによる分だけ増すことはいら までもない。

模型の静的 3 分力特性は, 別な実験により, 大型風洞 （高さ $\times$ 幅 $=2 \mathrm{~m} \times 4 \mathrm{~m}$ ）において 6 分力天秤を使用して 求められた ${ }^{12)}$ 。図一3 (a)〜 (d) にその結果を示す。矩 形断面柱の空力特性は断面比 $d / h$ により異なる。 $1: 1$ および $1: 2$ 断面柱は, 迎角 $0^{\circ}$ において, 前縁ではく離 したせん断層 (shear layer) の広がりが大きく上下面に 再付着しない例である。これに対し， $1: 4$ および $1: 5$ 断面柱は，せん断層が上下面に再付着し，はく離バブル (separation bubble) の生じた典型である。以下に前者 を完全はく離型，後者を再付着型と略称するが，いずれ の場合も $\alpha=0^{\circ}$ 付近で復元 モーメントを発生する。図 に示した $x_{p}=0$ におけるモーメント勾配を $C_{M \alpha_{0}}$ とす れば, 任意の軸位置 $x_{p}$ における モーメント勾配 $C_{M \alpha}$ は

$$
C_{M \alpha}=C_{M \alpha_{0}}+\left(C_{L_{\alpha}}+C_{D}\right) \frac{x_{p}}{2}
$$

により求められる。すなわち, $C_{M \alpha}$ は軸位置 $x_{p}$ に比 例して変化する。

図一4 にオッシログラフの記 録例, 図一5 にリミッ ト・サイクルの振幅の無次元風速 $\bar{V}(=V / f b)$ に対する 変化を示す。はく離流フラッタの特徴として, 安定なリ ミット・サイクル（印）のほが不安定なリミット・ サイクル ( $\times$ 印) が存在する場合がある。すなわち，振 動が $\theta<\theta_{0}$ で発散, $\theta>\theta_{0}$ で減衰であれば， $\theta_{0}$ は安 定なリミット・サイクルの振幅であり，逆に， $\theta<\theta_{0}$ で減衰， $\theta>\theta_{0}$ で発散であれば， $\theta_{0}$ は不安定なリミッ ト・サイクルの振幅を与える。安定なリミット・サイク ルはしばしば大振幅となり, ばねの直線限界 $\left( \pm 25^{\circ}\right)$ を 越えるので，このような場合は手によって振動を制止し た。

図一6 (a)〜 (d) は空力ねじりモーメントの無次元ダ ンピング $k_{a}$ のねじり軸位置 $x_{p}$ に対する変化である。 式 (8) で求めた定常 モーメント勾配 $C_{M \alpha}$ の変化も同 時に記す。 $k_{a}$ は無次元風速 $\bar{V}=50$ および 100 におけ る值である。これらの無次元風速の值が 2. で述べた意 味で十分大きいかどうかが問題であるが, 物体近傍 $(-1$ $\left.\leq x_{p} \leq 1\right)$ に関する限 り， $k_{a}$ の符号は同一であり， この条件は満足されていると考えられる。一方，模型の 振動が安定あるいは不安定なリミット・サイクルをもつ といらことは, 式 (5)〜 (7) で求められる $k_{a}$ の值が一 般に振幅により異なることを意味するものであるが，図 


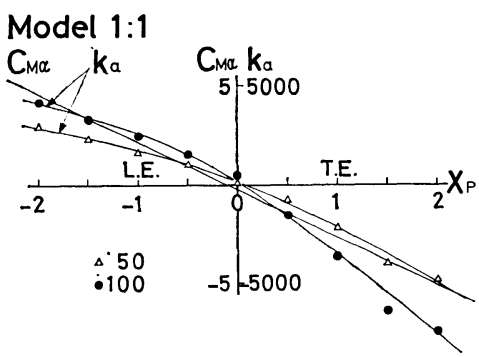

(a)

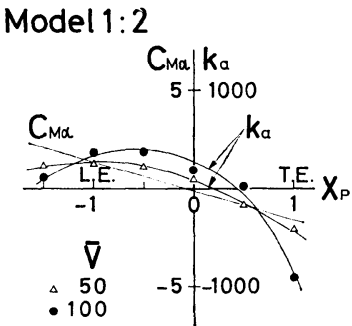

(b)

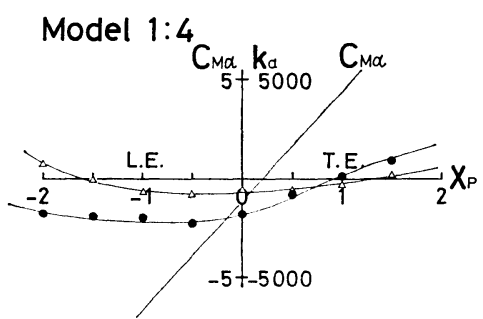

(c)

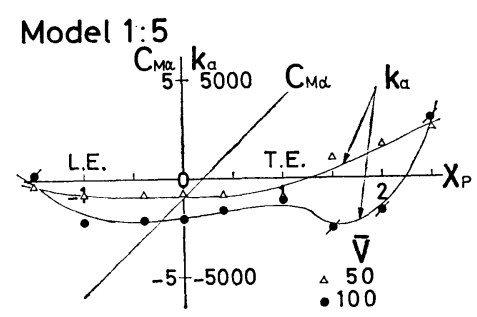

(d)
図一6 非定常空カねじりモーメントの無次元ダンピングと 定常モーメント勾配のねじり軸位賗に対する变化
用性を持たないといえる。

\section{4. 振動物体に作用する非 定常空力ねじりモーメ ント}

前節で示したように， $C_{M \alpha}$ に よるねじりフラッタの安定判別 に, あまり広い適用性は望み得な い。それにしても， $C_{M \alpha}$ 判別は いかなる根拠があるであろらか。 このことを検討するために，ねじ り振動を行なら物体に作用する非 定常空力ねじりモーメントについ て若干の考察を試みることにす る。

鈍い物体がある軸のまわりにね じり振動 $\theta(t)$ をしている場合を 考えよう。まず，準定常流を仮定 すると，物体に作用する空力ねじ
一6 に示したものは振幅 $\pm 2^{\circ}$ における值である。微小 線型振動を論ずるためには，この基準振幅はできるだけ 小さいほうが望ましい。しかし，測定精度上それには限 界がある。振幅 $2^{\circ}$ を選んだ理由は， $\bar{V}=50$ 100 にお いて, 多くの場合, $2^{\circ}$ 以下に安定および不安定なリミ ット・サイクルがなかったことによる。ただし，1:5 断 面柱ではなお，振幅の影響の著しい場合があった（図中 斜線付きで表示)。これらの測定点では, $2^{\circ}$ 以下の振幅 における $k_{a}$ の值が 図一6 (d) に記したものと大きく異 なることがあり得るわけである。逆に，これらの特別な 点以外では振幅の影響は比較的小さく, $k_{a}$ の值は $2^{\circ}$ 以 下でほぼ同じとみることができる。幸いに，以下に着目 する物体近傍にねじり軸がある場合は $\left(-1 \leq x_{p} \leq 1\right)$ いずれも振幅の著しい影響は認められなかった。

さて，図一6において， $k_{a}$ のねじり軸位置に対する 変化は， $\bar{V}=50$ でも 100 でも傾向的に一致する。また， 完全はく離型では上方に凸, 再付着型では下方に凸であ るようにみえるが，このことは，既述のねじり軸位置が 物体を遠く離れると並進運動に一致するといらことに対 応する（完全はく離型では負の揚力傾斜の存在のため, 並進運動は不安定, 逆に, 再付着型では正の揚力傾斜の ため, 並進運動は安定である)。

ここで, 物体近傍にねじり軸がある場合に限り， $C_{M \alpha}$ の符号と振動の安定性との関係を調べると, 完全はく離 型では両者は傾向的に一致するが，再付着型では必ずし も一致しないことがわかる。このような結果から考え て， $C_{M \alpha}$ によるねじりフラッタの判別はあまり広い適
りモーメント $\bar{M}(\theta)$ は，物体の現在の姿勢 $\theta$ ならびに その速度 $\dot{\theta}$, 加速度 $\ddot{\theta}, \cdots$ によって定まることになる。 ここで, ゆっくりした単振動 $\theta=\theta_{0} e^{i \omega t}$ を対象にして $\ddot{\theta}$ 以下の影響を無視すると，

$$
\bar{M}(\theta)=\bar{M}_{\theta} \theta+\bar{M}_{\theta} \dot{\theta}
$$

とかける。 $\bar{M}_{\theta}$ は姿勢 $\theta$ で静止する物体に㗢く定常モ ーメント勾配に等しい。また， $-\bar{M}_{\dot{\theta}}$ を準定常流的空力 ダンピングと呼ぶことにする。

特に, 中央弦長点でねじり振動をする薄翼を考える と, $\bar{M}_{\dot{\theta}}$ は, キャンバーが $z=-x^{2} \dot{\theta} / 2 V$ で与えられる ような定常翼に作用するモーメントに等しい。このよう な効果は動的キャンバー (dynamic camber) 効果と呼 ばれている。Steinman ${ }^{4}$ は，運動の相対性の考察より， 動的キャンバーの概念がはく離流の場合もポテンシャル 流と同様に成りたち, 準定常流的空力ダンピングをいわ ゆる曲線模型 (curved model) の定常モーメントより推 定することを提案した。たとえば，図一1における振動 物体の非定常モーメントを図一7のような静止模型の定 常モーメントで置き換えることになる。はく離流の場合 流れの相似が一般に成りたつとは思われず, Steinman のように両者の定量的一致を期待することは無理がある よらに考えられる。しかし， はく離したせん断層まで含め て十分に細長い場合に（たと えば, 細長い矩形断面柱), 二つの流れの定性的相似性を 仮定することは許されよう。

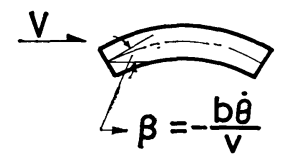

図一7動的キャンバー 効果 
ところで, 流れの中で振動する物体の空カダンピング を求める場合, 式（9）で考えた準定常効果以外にもう 1 つの効果を考慮する必要がある。それは流れの非定常 性である（流れの遅れといってもよい）。すなわち，物 体の姿勢 $\theta$ あるいは速度 $\dot{\theta}$ が変化したとき流れは瞬間 的に応答せず，物体周辺に生じたはく離流の変化が主流 により後方に伝えられるまで定常状態に達し得ない。こ れが，ここでいら流れの遅れにほかならない。したがっ て, 流れの遅れを考慮すると, 物体に働く非定常空力ね ビりモーメント $M(\theta)$ は, 式 (9) の準定常流的応答 に, それぞれの運動, $\theta$ と $\dot{\theta}$, に対するある周波数応答 が加わることになる。これらの周波数応答関数をそれぞ れ $C_{\theta} e^{i \varphi_{\theta}}$ および $C_{\dot{\theta}} e^{i \varphi_{\dot{\theta}}}$ と書くと, $M(\theta)$ は

$$
\begin{aligned}
M(\theta) & =M_{\theta} \theta+M_{\dot{\theta}} \dot{\theta} \\
& =C_{\theta} e^{i \varphi_{\theta}} \bar{M}_{\theta} \theta+C_{\dot{\theta}} e^{i \varphi_{\dot{\theta}} \bar{M}_{\dot{\theta}} \dot{\theta}}
\end{aligned}
$$

となる。式 (10) より非定常空力ダンピングを求める と,

$$
-M_{\dot{\theta}}=-C_{\dot{\theta}} \cos \varphi_{\dot{\theta}} \bar{M}_{\dot{\theta}}-\frac{C_{\theta} \sin \varphi_{\theta}}{\omega} \bar{M}_{\theta} \cdots
$$

ゆっくりした振動では, $C_{\theta}=C_{\dot{\theta}}=1,\left|\varphi_{\theta}\right|,\left|\varphi_{\dot{\theta}}\right| \ll 1$ とし てよいから, 式 (11) は

$$
-M_{\dot{\theta}}=-\bar{M}_{\dot{\theta}}-\frac{\sin \varphi_{\theta}}{\omega} \bar{M}_{\theta}
$$

と書ける。ここで，右辺第 1 項は準定常流的空力ダンピ ングであり，第 2 項は流れの遅れによる成分である。こ のように, 非定常空力ダンピングは 2 つの異なる効果の 和よりなっていることがわかる。今, 式 (12) で右辺第 2 項が支配的であれば, ねじりフラッタは流れの遅れに よって発生するといってよい。その場合，特に $\varphi_{\theta}<0$ （遅れ，多くの場合成立するであろう）を仮定すると， 定常モーメント勾配 $\bar{M}_{\theta}$ (無次元化すれば $C_{M \alpha}$ ) の負 または正に対応して $-M_{\dot{\theta}}$ の符号は負または正になる。 すなわち，2. で述べた $C_{M \alpha}$ による判別はこの場合妥 当性をもつ。しかし, 流れの遅れが支配的であっても, $\varphi_{\theta}<0$ でなければ $C_{M \alpha}$ 判別は妥当しない。また, 式 (12) の右辺においてもし第 1 項が支配的であれば，ね じりのフラッタは準定常効果によって発生したというべ きであろう。

物体の形とねじり軸位置を与えて, 式 (12) の右辺第 1 項と第 2 項とを独立に評価することは現在可 能でな く, 将来の研究にまたなければならない。ギャロッピン グはこの点においてねじりフラッタと対蹠的である。す なわち, 並進運動において式（9）と同様に準定常揚力 $\bar{L}(z)$ を

$$
\bar{L}(z)=\bar{L}_{z} z+\bar{L}_{\dot{z}} \dot{z}
$$

と記すと, $\bar{L}_{z}=0$, よって, 並進運動の非定常揚力にお いては, 式 (12) の右辺第 2 項のような流れの遅れによ
る項が現われず，準定常理論がよい近似を与える。

\section{5. 流れの遅れとねじりフラッタの発生}

さて, $C_{M \alpha}$ の符号と振動の安定性との関係について, 完全はく離型ではこの両者が傾向的に一致し，再付着型 では必ずしも一致しないことが 3. の実験結果より認め られた。前節の議論を基礎にしてこのことを考察する と, 完全はく離型の場合は流れの遅れの効果が大きく, 逆に, 再付着型の場合は準定常効果が無視し得ないであ ろらことが推定される。しかし, 再付着型のような細長 い矩形断面柱でも，なお，流れの遅れを無視するとねじ りのフラッタが説明できない例として, 前縁にねじり軸 がある場合をあげることができる。図一8によって, $\theta$ $=0, \dot{\theta}>0$ の状態を考える。断面が細長いので, 準定 常近似においてキャンバー効果を考えることは，定性的 議論に限り許されよう。よって, 準定常近似では 図一8 (b) が対応し, 流れのパターンとして, 上面のはく離バ ブルが拡大し，下面のはく離バブルが縮少することが推 定される。再付着点以後で強い圧力上昇があることを考 慮すると, 図一8 (b) の場合, 前縁まわりに反時計方向 のモーメントが作用することになる。振動物体ではこれ は正減衰 モーメントの発生を意味する。しかし, 図一6 (c), (d) の実験結果 では, $x_{p}=-1$ において $k_{a}<0$, すなわち，振動は発散するので，このことは明らかに矛 盾である。一方, 流れの遅れを考えると, 図一8 (c) に 示すパターンが期待され，したがって振動物体では負減 衰モーメントが対応し，実験結果と一致する。完全はく 離型では, 断面が十分細長いといい難いので, 準定常近 似においてキャンバー効果を考えることは若干疑問があ るが，なお，同様な推論を行ならことができる。この場 合, 実験結果が正減衰であるのに対し, 準定常近似では 負減衰, 流れの遅れによれば正減衰となり, やはり後者 が実験結果と一致する。

以上の推論を確かめるために, 前縁を軸としてねじり 振動を行なら模型について，煙による流れの観察を行な い，図一8 (b)，(c) のいずれのパターンが実現するか 調べてみた。実験結果は, 写真一2 (a), (b) に示すご とく, 流れのパターンに関しては流れの遅れの効果が支 配的であることを示しており，上記推論を支持するよう にみえる。ただし，写真一2 では，流れの変化を誇示す

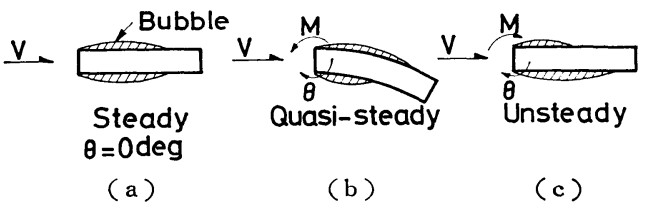

図一8 前緑を軸としてねじり振動する矩形断面柱 


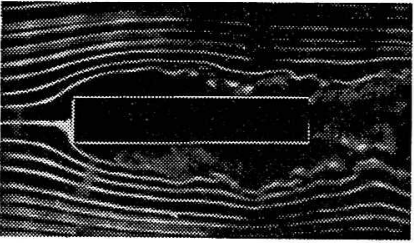

(a)

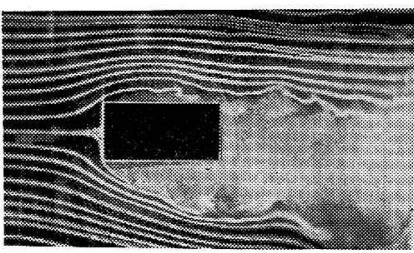

(b)

$\bar{V}=40, \theta=0^{\circ}$

(a) $1: 5$ 断面柱, 振幅 $\pm 6^{\circ}$

(b) $1: 2$ 断面柱, 振幅 $\pm 10^{\circ}$

写真一2 前縁を軸としてねじり

振動する矩形断面柱の

煙による流れの観察
時計まわり $(\dot{\theta}>0)$

るために低風速, 大 振幅の例を示し，図 一6に拈ける実験条 件と一致しないが, 高風速, 小振幅でも 流れの遅れが認めら れることは 写真一2 と同様であった。

ねじりの 1 自由度 フラッタにおいて， 流れの遅れが支配的 な役割を演ずること は，翼の場合すでに 教科書に記されてい る ${ }^{13)}$ 。今，衿じり軸 位置 $x_{p}$ においてゆ っくりしたねじり振 動它行なら平板翼に つき, 加速度 $\ddot{\theta}$ の 影響を無視してその非定常空力ねじりモーメントを記す と,

$$
\begin{aligned}
M(\theta)= & -\pi \rho b^{3} V\left(\frac{1}{2}-x_{p}\right) \dot{\theta} \\
& +2 \pi \rho b^{2} V\left(\frac{1}{2}+x_{p}\right) C(k) \\
& \cdot\left[V \theta+b\left(\frac{1}{2}-x_{p}\right) \dot{\theta}\right] .
\end{aligned}
$$

となる。ここに，右辺第 1 項，第 2 項はともに循環流の 寄与であるが，第 2 項 が流れの遅れに 関係する。C $(k)$ $(=F(k)+i G(k), k=2 \pi / \bar{V})$ は Theodorsen 関数であ る。

式（14）において, $C(k)=1(F(k)=1, G(k)=0)$ と おいたものが準定常近似である。すなわち,

$$
\begin{aligned}
\bar{M}(\theta)= & -\pi \rho b^{3} V\left(\frac{1}{2}-x_{p}\right) \dot{\theta} \\
& +2 \pi \rho b^{2} V\left(\frac{1}{2}+x_{p}\right) \\
& \cdot\left[V \theta+b\left(\frac{1}{2}-x_{p}\right) \dot{\theta}\right]
\end{aligned}
$$

一方, 式 (12) 右辺第 2 項に相当して, 空力ダンピング における流れの遅れの寄与を求めると,

$$
-\frac{\sin \varphi_{\theta}}{\omega} \bar{M}_{\theta}=-\rho b^{3} V \bar{V}\left(\frac{1}{2}+x_{p}\right) G(k) \cdots
$$

式 (14)〜 (16) における空力ダンピングを式（6）によ り無次元化して示したものが 図一9 である。流れの遅 れを無視した準定常理論が，前縁付近で生ずるねじりフ ラッタを説明し得ないことがわかるであろう。このよ5 な流れの遅れの効果に関しては, 細長い矩形断面柱でも

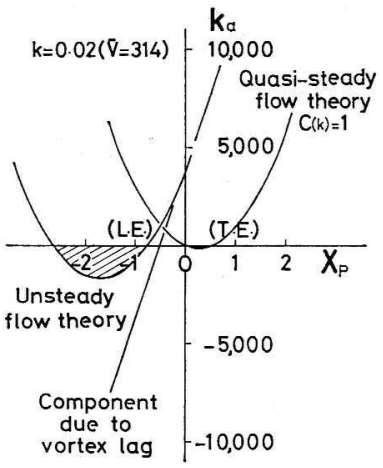

図一9 平板翼における非定常 空力ねじりモーメント の無次元ダンピング

翼と同様な事情が生ずるものと思われる。

\section{6. 結 論}

断面比 1:1，1:2,1:4 および 1:5の 4 種類の矩 形断面柱に関し，風洞実験を行ない，そのねじりフラッ タを研究した。その結果，次のことが判明した。

（1）定常モーメント勾配の符号によるねじりフラッ タの判別は高無次元風速（ゆっくりした振動）ならびに 物体近傍にねじり軸がある場合にのみ適用されるべきで ある。

（2）そのような適用限界を認めても，なお，上記判 別は広い適用性を持ち得ない。実験結果によると，完全 はく離型の $1: 1$, および $1: 2$ 断面柱について上記判 別はほぼ妥当するが，再付着型の $1: 4$, および $1: 5$ 断面柱については必ずしも妥当しなかった。

（3）ゆっくりした振動においては, 非定常ねじりモ ーメントの空力ダンピングは, 一般に, 流れの遅れによ る成分と準定常流的成分とよりなる。

（4）ねじりフラッタにおいて, 流れの遅れが支配的 である場合に上記判別は妥当するが，準定常効果が無視 し得ないときは必ずしも妥当しない。

（5）再付着型の細長い矩形断面柱においても，な お，前縁近傍にねじり軸がある場合は，ねじり振動の安 定性に詨して流れの遅れによる効果が支配的である。

おわりに, 本研究の風洞実験を行ならについては, 研 究室諸氏の全面的協力を得たことを記し，ここに謝意走 表する次第である。

\section{参 考 文 献}

1) Novak, M. : Galloping oscillations of prismatic structures, J. Engrg. Mech. Div., Proc. A.S.C.E., Vol. 98, No. EM 1, pp. 27-46, Feb., 1972

2) Ericsson, L.E. and J.P. Reding : Unsteady airfoil stall-Review and extension, AIAA Paper No. 70- 
77, Jan., 1970

3) Farquharson, F.B. : Aerodynamic stability of suspension bridges with special reference to the Tacoma Narrows Bridge, Bull. Univ. Washington Engrg. Exp. Station, No. 116, Part 1, p. 33, 1949

4) Steinman, D.B. : Aerodynamic theory of bridge oscillations, Trans. A.S.C.E., Vol. 115, pp. 1180-1217, 1950

5）宮田利雄・岡内 功：吊橋の風による自励振動に関する一 考察, 土木学会論文集, 第 173 号, pp. 19-34, 1970

6) Wardlaw, R.L. : Wind-excited vibrations of slender beams with angle cross sections, Proc. Int. Conf. Wind Effects on Buildings and Structures, Canada, Vol. 1, Univ. Toronto Press, pp. 739-772, 1967

7) Scanlan, R.H. : An examination of aerodynamic response theories and model testing relative to suspension bridges, Proc. 3 rd Int. Conf. Wind Effects on Buildings and Structures, Tokyo, Saikon, Co. Ltd., Tokyo, pp. 941-952, 1971

8) Modi, V.J. and J.E. Slater : Quasi-steady analysis of torsional aeroelastic oscillators, Paper presented at IUTAM Symp. Flow-induced Structural Vibrations, Karlsruhe, Aug., 1972

9) Task Committee on Wind Forces: Wind forces on structures, Trans. A.S.C.E., Vol. 126, Part II, p. 1174,1961

10) Otsuki, Y., K. Washizu, H. Tomizawa, A. Ohya and K. Fujii : Experiments on the aeroelastic instability of prismatic bars with rectangular sections, Proc. 3rd Int. Conf. WEBS, pp. 891-898, 1971

11）中村泰治・溝田武人：ある箱型構造物の空力弾性的特性 について, 構造物の耐風性に関する第 2 回シンポジウム 論文集, 東京, pp. 151-158, 1972

12）中村泰治・溝田武人・吉村 健 : 矩形およびH型断面材の 静的 3 分力特性について, 土木学会西部支部研究発表会 論文集, Feb., 1973

13) Bisplinghoff, R.L., H. Ashley and R.L. Halfman : Aeroelasticity, Addison-Wesley, Inc., Reading, Massachusetts, p. 528,1955

(1973.2.5 - 受付) 